\title{
Salicylic Acid Stimulates Antioxidant Defense and Osmolyte Metabolism to Alleviate Oxidative Stress in Watermelons under Excess Boron
}

\author{
Mohamed Moustafa-Farag 1,2,3(-), Heba I. Mohamed ${ }^{4}$, Ahmed Mahmoud ${ }^{1,2}{ }^{(0)}$, Amr Elkelish ${ }^{5}{ }^{(0)}$, \\ Amarendra N. Misra ${ }^{6,7}$, Kateta Malangisha Guy ${ }^{1}$, Muhammad Kamran ${ }^{3}$, Shaoying $\mathrm{Ai}^{3}$ and \\ Mingfang Zhang ${ }^{1, *}$ \\ 1 Lab of Germplasm Improvement and Molecular Breeding, Agriculture and Biotechnology College, \\ Zhejiang University, Hangzhou 310029, China; m_m_kamel2005@gdaas.cn (M.M.-F.); \\ 11716103@zju.edu.cn (A.M.); malangisha@zju.edu.cn (K.M.G.) \\ 2 Horticulture Research Institute, Agriculture Research Center, Giza 12619, Egypt \\ 3 Institute of Agricultural Resources and Environment, Guangdong Academy of Agricultural Sciences, \\ Guangzhou 510640, China; drkamran2017@nwsuaf.edu.cn (M.K.); aishaoying@gdaas.cn (S.A.) \\ 4 Biological and Geological Sciences Department, Faculty of Education, Ain Shams University, \\ Cairo 11566, Egypt; hebaebrahem@edu.asu.edu.eg \\ 5 Botany Department, Faculty of Science, Suez Canal University, Ismailia 41522, Egypt; \\ amr.elkelish@science.suez.edu.eg \\ 6 Department for Life Sciences, Central University of Jharkhand, Brambe, Ranchi-835205, India; anm@cuj.ac.in \\ 7 Department of Biosciences \& Biotechnology, Khallikote University, GMax Building, Konishi, \\ Berhampur 761008, India \\ * Correspondence: mfzhang@zju.edu.cn
}

Received: 18 May 2020; Accepted: 2 June 2020; Published: 8 June 2020

\begin{abstract}
Boron (B) is a microelement required in vascular plants at a high concentration that produces excess boron and toxicity in many crops. B stress occurs widely and limits plant growth and crop productivity worldwide. Salicylic acid (SA) is an essential hormone in plants and is a phenolic compound. The goal of this work is to explore the role of SA in the alleviation of excess $B$ $\left(10 \mathrm{mg} \mathrm{L}^{-1}\right)$ in watermelon plants at a morphological and biochemical level. Excess boron altered the nutrient concentrations and caused a significant reduction in morphological criteria; chlorophyll a, $\mathrm{b}$, and carotenoids; net photosynthetic rate; and the stomatal conductance and transpiration rate of watermelon seedlings, while intercellular carbon dioxide $\left(\mathrm{CO}_{2}\right)$ was significantly increased compared to the control plants $\left(0.5 \mathrm{mg} \mathrm{L}^{-1} \mathrm{~B}\right)$. Furthermore, excess boron accelerated the generation of reactive oxygen species (ROS), such as hydrogen peroxide $\left(\mathrm{H}_{2} \mathrm{O}_{2}\right)$ and induced cellular oxidative injury. The application of exogenous SA significantly increased chlorophyll and carotenoid contents in plants exposed to excess $B\left(10 \mathrm{mg} \mathrm{L}^{-1}\right)$, in line with the role of SA in alleviating chlorosis caused by $B$ stress. Exogenously applied SA promoted photosynthesis and, consequently, biomass production in watermelon seedlings treated with a high level of $B\left(10 \mathrm{mg} \mathrm{L}^{-1}\right)$ by reducing $B$ accumulation, lipid peroxidation, and the generation of $\mathrm{H}_{2} \mathrm{O}_{2}$, while significantly increasing levels of the most reactive $\mathrm{ROS}, \mathrm{OH}^{-}$. SA also activated antioxidant enzymes, such as superoxide dismutase (SOD), peroxidase (POD), and ascorbate peroxidase (APX) and protected the seedlings from an ROS induced cellular burst. In conclusion, SA can be used to alleviate the adverse effects of excess boron.
\end{abstract}

Keywords: salicylic acid; chlorophyll fluorescence; excess boron; lipid peroxidation; enzymatic antioxidant; glutathione; proline; stomatal conductance 


\section{Introduction}

Boron (B) is an essential plant micronutrient and has a functional role in the creation and function of cell walls [1]. Boron stress causes drastic effects worldwide. Toxic concentrations of B occur in soils that are irrigated with water contaminated with B or an excessive use of B-rich fertilizer, sewage sludge, as well as natural deposits discovered throughout the globe in arid and semi-arid areas [2]. Boron stress induces certain biochemical and morphological failures, such as reduced shoot and root development [3,4]; photosynthesis inhibition; reduced stomatal conductance [5]; the generation of reactive oxygen species (ROS) causing oxidative stress to lipids, proteins, and nucleic acids [6]; reduced root proton extrusion [7], reduced root cell division [8]; lignin and suberin accumulation in roots [9]; increased permeability of the membrane; lipid peroxidation; and altered antioxidant enzyme activities [10]. Scientists have been interested in developing potential strategies to enhance the seeds germination and the plants growth to achieve higher crop production [11,12]. Using phytohormones such as salicylic acid (SA) can enhance plant tolerance and counteract the toxic impacts of heavy metals on the germination of seedlings and the growth and development of plants. SA is a natural plant hormone that acts as a signal molecule to regulate plant growth [11], seedling germination, glycolysis, the flowering process, fruit yield [11], the uptake and transport of ions [12], stomatal conductance, the transpiration and photosynthetic rate [13], and the regulation of antioxidant enzyme synthesis during both biotic and abiotic stress [14,15]. Additionally, SA is a crucial signal biomolecule mediated systemic resistance to pathogen attacks by plants [16]. SA has also been shown to protect winter wheat plants [17] against cold stress and heat stress [18,19] and to modulate plant responses to salt and osmotic stresses [15,20], ozone or UV light [21], drought [22], and heavy metals, such as Cd [23-27], $\mathrm{Mn}$ [28], $\mathrm{Hg}$ [29], B [30], and $\mathrm{Pb}$ [31].

Although SA is widely used to protect economic crops against abiotic stress, only a few reports investigated its protective impact under excess boron stress [32,33]. SA protects plants under excess boron associated salinity, such as spinach [34]. The protective role of SA is expressed mainly by regulating ROS and antioxidants, inducing gene expression, and absorbing and distributing elements $[23,35,36]$. The most effective effect of SA is to improve the function of antioxidant enzymes in vivo $[37,38]$. Although the role of SA in the antioxidant system is very well studied under different biotic and abiotic stresses [14,39], its role under B stress remains unclear. In addition, the relationship between SA and boron toxicity has had contrary results in different studies. For instance, in mung beans, SA inhibits lipid peroxidation and reduced boron toxicity disorders through a reduction in lipoxygenase activity [40]. Watermelon belongs to the Cucurbitaceous family and is considered one of the world's top 20 cultivated crops with elevated economic value. The principal countries producing watermelon, such as China and Turkey [41,42], are affected by B stress, which has drastic effects on watermelon growth and yield. Nevertheless, there is insufficient knowledge on the mechanisms of boron toxicity-induced watermelons injury [4], highlighting the importance of alleviating B stress in watermelon crops.

Therefore, the aim of the present study is to (1) study the different responses of excess boron on watermelon and (2) evaluate the changes induced by SA in the antioxidant system and mineral uptake during excess boron stress. This research will help us to understand the mechanisms associated with excess boron in watermelon, help recommend the correct treatment of SA to alleviate B stress and aid the scientific community in solving the B stress problem.

\section{Results}

\subsection{Plant Growth}

The results show that the shoot and root dry weight of watermelon plants is significantly reduced by excess boron compared to control plants. In addition, the root projected area, surface area, diameter, volume, and number of tips was significantly decreased under excess boron except root volume, 
which experienced insignificant effects (Table 1$)$. On the other hand, SA treatment $(0.3 \mathrm{mM})$ increased watermelon growth and development under excess boron (Table 1).

Table 1. Effect of $0.3 \mathrm{mM}$ salicylic acid (SA) on watermelon root system development under excess boron at 35 days old.

\begin{tabular}{|c|c|c|c|c|c|c|c|}
\hline Treatment & $\begin{array}{l}\text { Shoot Dry } \\
\text { Weight }\end{array}$ & $\begin{array}{c}\text { Root Dry } \\
\text { Weight }\end{array}$ & $\begin{array}{l}\text { Project Area } \\
\left(\mathrm{cm}^{2}\right)\end{array}$ & $\begin{array}{c}\text { Surface } \\
\text { Area }\left(\mathrm{cm}^{2}\right)\end{array}$ & $\begin{array}{c}\text { Avg Diameter } \\
(\mathrm{mm})\end{array}$ & $\begin{array}{l}\text { Root Volume } \\
\qquad\left(\mathrm{cm}^{3}\right)\end{array}$ & $\begin{array}{c}\text { Number of } \\
\text { Tips }\end{array}$ \\
\hline Control & $7.0 \pm 0.42^{a}$ & $0.17 \pm 0.010^{b}$ & $42.85 \pm 2.57^{b}$ & $90 \pm 5.4^{c}$ & $0.64 \pm 0.04^{\mathrm{d}}$ & $1.48 \pm 0.09^{b}$ & $3173 \pm 190^{b}$ \\
\hline Excess B & $1.54 \pm 0.09^{\mathrm{d}}$ & $0.11 \pm 0.007^{\mathrm{e}}$ & $20.25 \pm 1.21^{e}$ & $59 \pm 3.6^{e}$ & $0.72 \pm 0.04^{c}$ & $1.23 \pm 0.07^{c}$ & $1161 \pm 69^{e}$ \\
\hline Control + SA & $3.78 \pm 0.29^{b}$ & $0.29 \pm 0.022^{a}$ & $51.16 \pm 3.99^{a}$ & $160 \pm 12.5^{a}$ & $0.80 \pm 0.06^{b}$ & $3.20 \pm 0.25^{a}$ & $4162 \pm 324^{a}$ \\
\hline Excess B + SA & $2.29 \pm 0.22^{c}$ & $0.14 \pm 0.014^{\mathrm{d}}$ & $24.03 \pm 2.40^{\mathrm{d}}$ & $73 \pm 7.4^{\mathrm{d}}$ & $0.49 \pm 0.05^{\mathrm{e}}$ & $1.54 \pm 0.15^{b}$ & $1921 \pm 192$ \\
\hline
\end{tabular}

Columns stand for mean \pm SD. ANOVA were analyzed variations between the four treatments. Various letters indicate a significant difference from $p<0.05$.

\subsection{Boron Uptake and Translocation}

The accumulation of boron in the roots and leaves of watermelon was increased significantly by approximately 5.5- and 10-fold, respectively, in response to excess boron stress compared to the untreated plants $\left(0.5 \mathrm{mg} \mathrm{L}^{-1}\right)$ (Table 2$)$. Watermelon plants translocated more B from the root to leaf tissues, as shown by the high translocation factor value (TF, the ratio of total $\mathrm{B}$ in the leaf and root tissues). The translocation factor showed a significant increase in excess boron treated plants. Treatment with SA caused a significant decrease in B contents in the roots and leaves of watermelon seedlings under excess boron stress compared to non-SA-treated plants.

Table 2. Effect of $0.3 \mathrm{mM}$ SA on boron (B) uptake and translocation on watermelon leaves and roots under excess boron at 35 days old.

\begin{tabular}{cccc}
\hline Treatment & B Level in Roots $\mathbf{( \mathbf { m g ~ k g } ^ { - 1 } )}$ & B Level in Leaves $\mathbf{( \mathbf { m g ~ k g } ^ { - 1 } )}$ & Translocation Factor \\
\hline Control & $73.9 \pm 3.05^{\mathrm{c}, \mathrm{d}}$ & $150.9 \pm 20^{\mathrm{c}}$ & $2.04 \pm 0.35^{\mathrm{b}}$ \\
Excess B & $408.0 \pm 40^{\mathrm{a}}$ & $1592.3 \pm 400^{\mathrm{a}}$ & $3.92 \pm 1.36^{\mathrm{a}}$ \\
Control + SA & $80.3 \pm 6^{\mathrm{c}}$ & $90.2 \pm 6^{\mathrm{c}}$ & $1.12 \pm 0.07^{\mathrm{c}}$ \\
Excess B + SA & $276.3 \pm 40^{\mathrm{b}}$ & $1146.3 \pm 200^{\mathrm{b}}$ & $4.18 \pm 1.33^{\mathrm{a}}$ \\
\hline
\end{tabular}

Columns stand for mean \pm SD. ANOVA were analyzed variations between the four treatments. Various letters indicate a significant difference from $p<0.05$.

\subsection{Mineral Uptake}

Without the SA treatment, a non-significant effect was found for the different macro-nutrients $\left(\mathrm{Ca}^{2+}, \mathrm{Mg}^{2+}\right.$ and $\left.\mathrm{K}^{+}\right)$in the shoots and root tissues under excess boron stress, but higher amounts of $\mathrm{Na}^{+}$was recorded in the shoots of watermelon and lower amounts in roots under excess boron (Table 3). In the presence of $\mathrm{SA}, \mathrm{Ca}^{2+}$ content was significantly reduced in shoots and a marked increase in roots compared to their respective non-SA plants under excess boron stress. Furthermore, treatment with SA caused a significant increase in the $\mathrm{K}^{+}$content of watermelon shoots but decreased in roots under excess boron stress. SA-treated plants under excess boron stress had more $\mathrm{Mg}^{2+}$ in their root tissues, although the concentration in shoots remained unaffected. In addition, SA significantly decreased the shoot $\mathrm{Na}^{+}$concentration in the boron-stressed plants and control plants. On the other side, the $\mathrm{Na}^{+}$ concentration increased dramatically in roots under excess boron and control conditions compared to non-SA plants (Table 3). 
Table 3. Effect of $0.3 \mathrm{mM} \mathrm{SA}$ on nutrient uptake and translocation in watermelon shoot and root tissues under excess boron at 35 days old.

\begin{tabular}{|c|c|c|c|c|}
\hline \multirow{2}{*}{ Treatment } & \multicolumn{4}{|c|}{ Macro-Nutrient (mg kg-1 Shoot DW) } \\
\hline & $\mathrm{Ca}^{2+}$ & $\mathrm{K}^{+}$ & $\mathrm{Mg}^{2+}$ & $\mathrm{Na}^{+}$ \\
\hline Control & $60.8 \pm 5.03^{\mathrm{a}}$ & $87.5 \pm 4^{b, c}$ & $16.1 \pm 2^{a}$ & $15.1 \pm 2^{c}$ \\
\hline Excess B & $56.9 \pm 4^{\mathrm{a}, \mathrm{b}}$ & $79.8 \pm 4^{c}$ & $14.0 \pm 2^{\mathrm{a}}$ & $19.0 \pm 2^{b}$ \\
\hline Control + SA & $54.6 \pm 4^{b}$ & $103.7 \pm 20^{\mathrm{a}}$ & $14.1 \pm 2^{\mathrm{a}}$ & $1.2 \pm 0.2^{\mathrm{d}}$ \\
\hline Excess B + SA & $49.8 \pm 4^{\mathrm{c}}$ & $96.7 \pm 12^{a, b}$ & $15.4 \pm 4^{\mathrm{a}}$ & $1.7 \pm 0.2^{\mathrm{d}}$ \\
\hline \multirow{2}{*}{ Treatment } & \multicolumn{4}{|c|}{ Macro-Nutrient (mg kg-1 Root DW) } \\
\hline & $\mathrm{Ca}^{2+}$ & $\mathrm{K}^{+}$ & $\mathrm{Mg}^{2+}$ & $\mathrm{Na}^{+}$ \\
\hline Control & $12.4 \pm 4^{\mathrm{c}}$ & $107.5 \pm 20^{a}$ & $3.4 \pm 0.4^{\mathrm{c}}$ & $4.2 \pm 0.4^{b}$ \\
\hline Excess B & $14.5 \pm 4^{c}$ & $112.8 \pm 20^{a}$ & $3.5 \pm 0.4^{c}$ & $3.4 \pm 0.4^{\mathrm{e}}$ \\
\hline Control + SA & $24.8 \pm 2^{b}$ & $68.2 \pm 4^{\mathrm{b}}$ & $6.0 \pm 0.2^{\mathrm{a}}$ & $8.9 \pm 0.2^{a}$ \\
\hline Excess B + SA & $22.7 \pm 2^{b}$ & $34.8 \pm 4^{c}$ & $4.9 \pm 0.2^{b}$ & $4.2 \pm 0.2^{b}$ \\
\hline
\end{tabular}

Columns stand for mean \pm SD. ANOVA were analyzed variations between the four treatments. Various letters indicate a significant difference from $p<0.05$.

\subsection{Chlorophyll and Carotenoid Content}

Excess boron stress caused a significant decrease in chlorophyll $a, b$, and carotenoid content in watermelon leaves compared to the untreated plants (Figure 1). The application of SA precipitated significant increases in chl a, chl b, and carotenoid content in stressed plants. These results confirm the role of SA in alleviating chlorosis symptoms caused by excess boron stress.
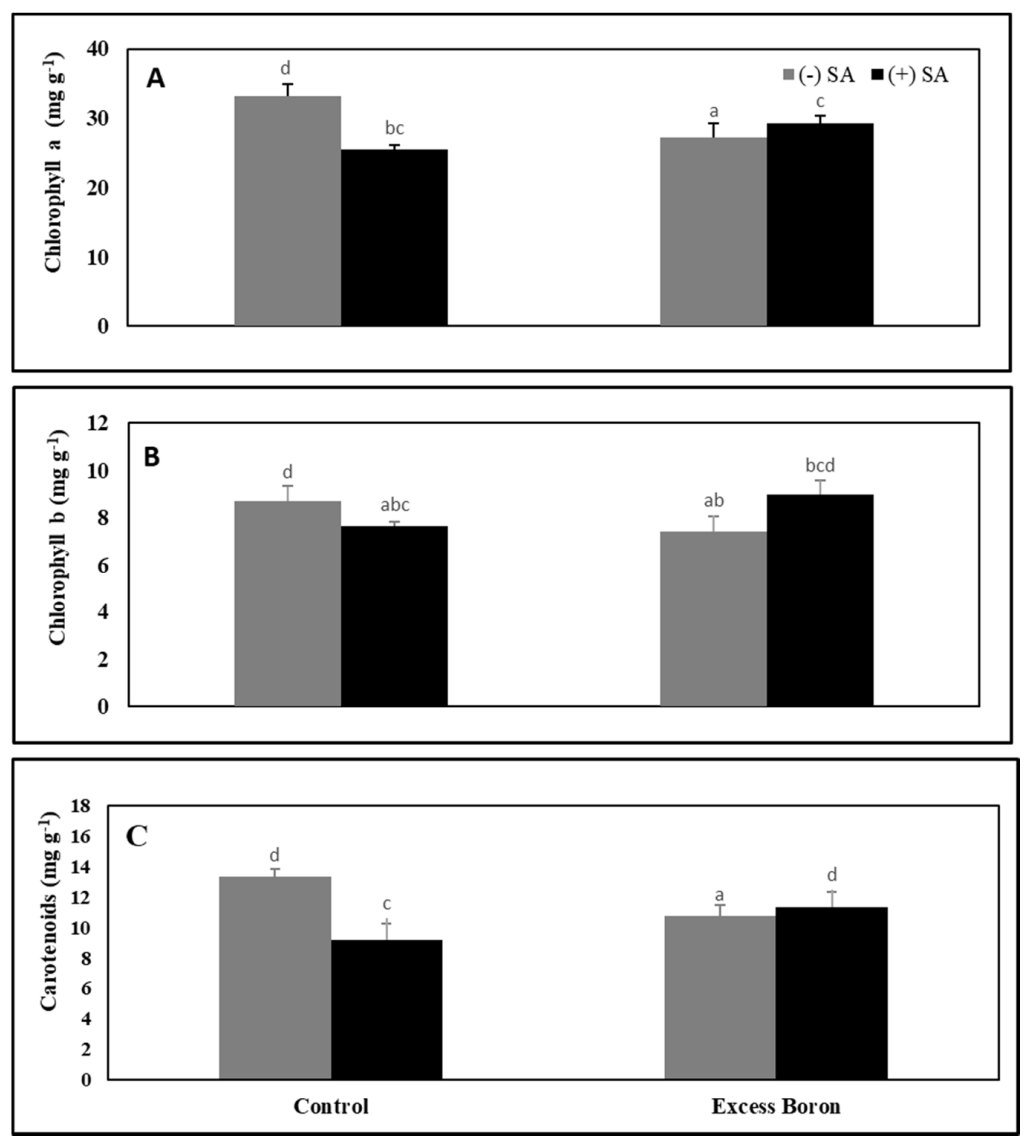

Figure 1. Effects of $0.3 \mathrm{mM} \mathrm{SA}$ on photosynthetic pigments (chlorophyll a (A), chlorophyll b (B) and carotenoids $(\mathbf{C})$ in leaves under excess boron at 35 days old. The bars stand for mean $\pm \mathrm{SD}$. ANOVA were analyzed variations between the four treatments. The various letters indicate a significant difference from $p<0.05$. 


\subsection{Leaf Gas Exchange}

Excess boron exhibited significantly decreased PN, Gs, and Tr in watermelon seedlings and increased intercellular carbon dioxide $\left(\mathrm{CO}_{2}\right)$ compared to the unstressed plants (Figure 2). In addition, treatment with SA induced a significant reduction in PN, Gs, Tr but a significant rise in intercellular carbon dioxide $\left(\mathrm{CO}_{2}\right)$ under excess boron and in the control (Figure 2).

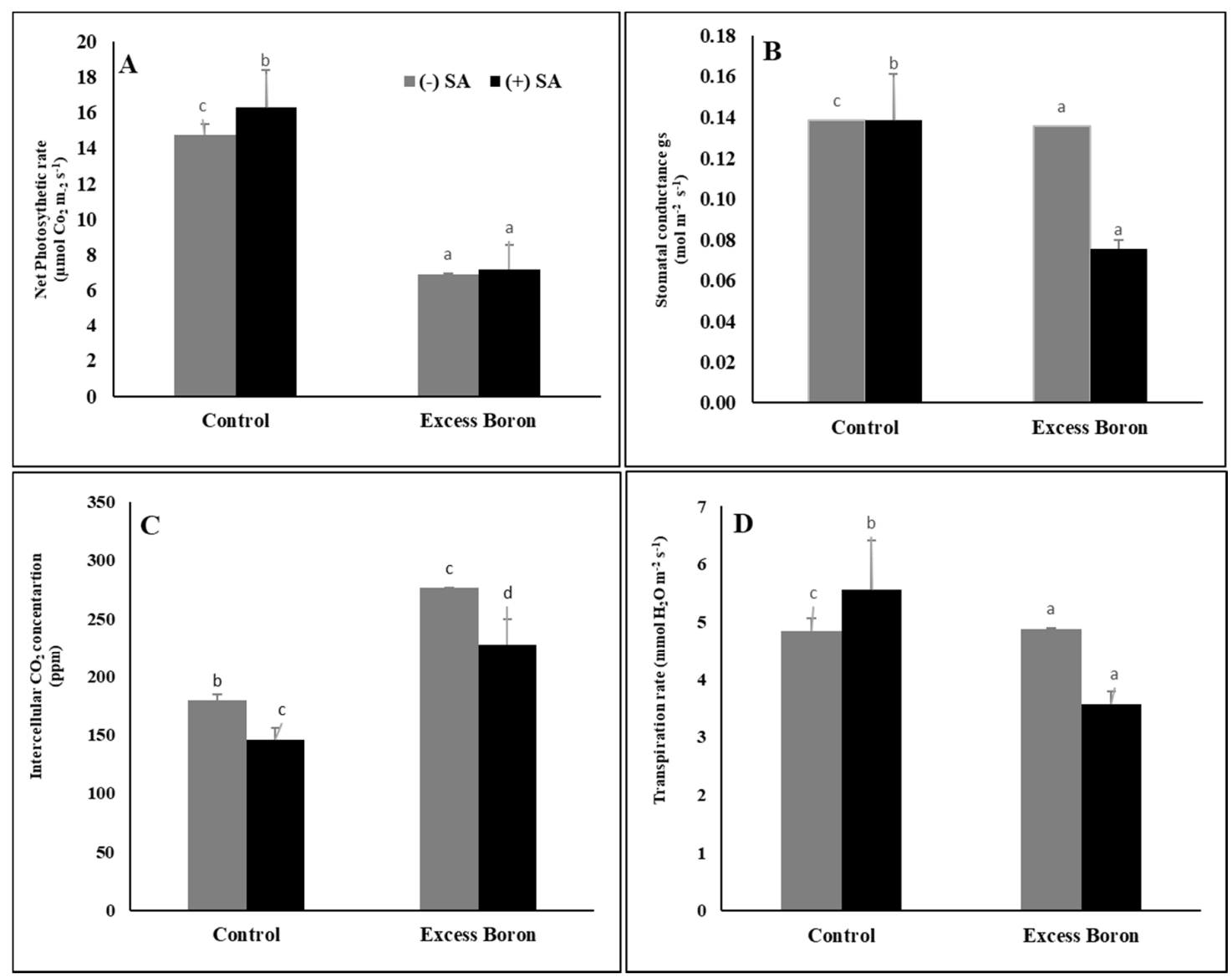

Figure 2. Effects of $0.3 \mathrm{mM}$ SA on leaf gas exchange under excess boron at 35 days old. (A) Net photosynthesis rate, (B) stomatal conductance, (C) intercellular $\mathrm{CO}_{2}$ concentration, and (D) transpiration rate. Bars stand for mean $\pm \mathrm{SD}$. ANOVA were analyzed variations between the four treatments. The various letters indicate a significant difference from $p<0.05$.

\subsection{Chlorophyll Fluorescence}

Under excess boron stress, there are variable responses in the chlorophyll fluorescence of watermelon leaves (Figure 3). Excess boron induced a significant reduction in Fm but exerted a non-significant effect in F0 and PSII (Fv/Fm) compared to the control plants (0.5 B). Treatment with SA was significantly decreased in the PSII ( $\mathrm{Fv} / \mathrm{Fm})$ of the plants under excess boron compared to the other treatments without SA (Figure 3), while F0 and Fm remained unaffected. 

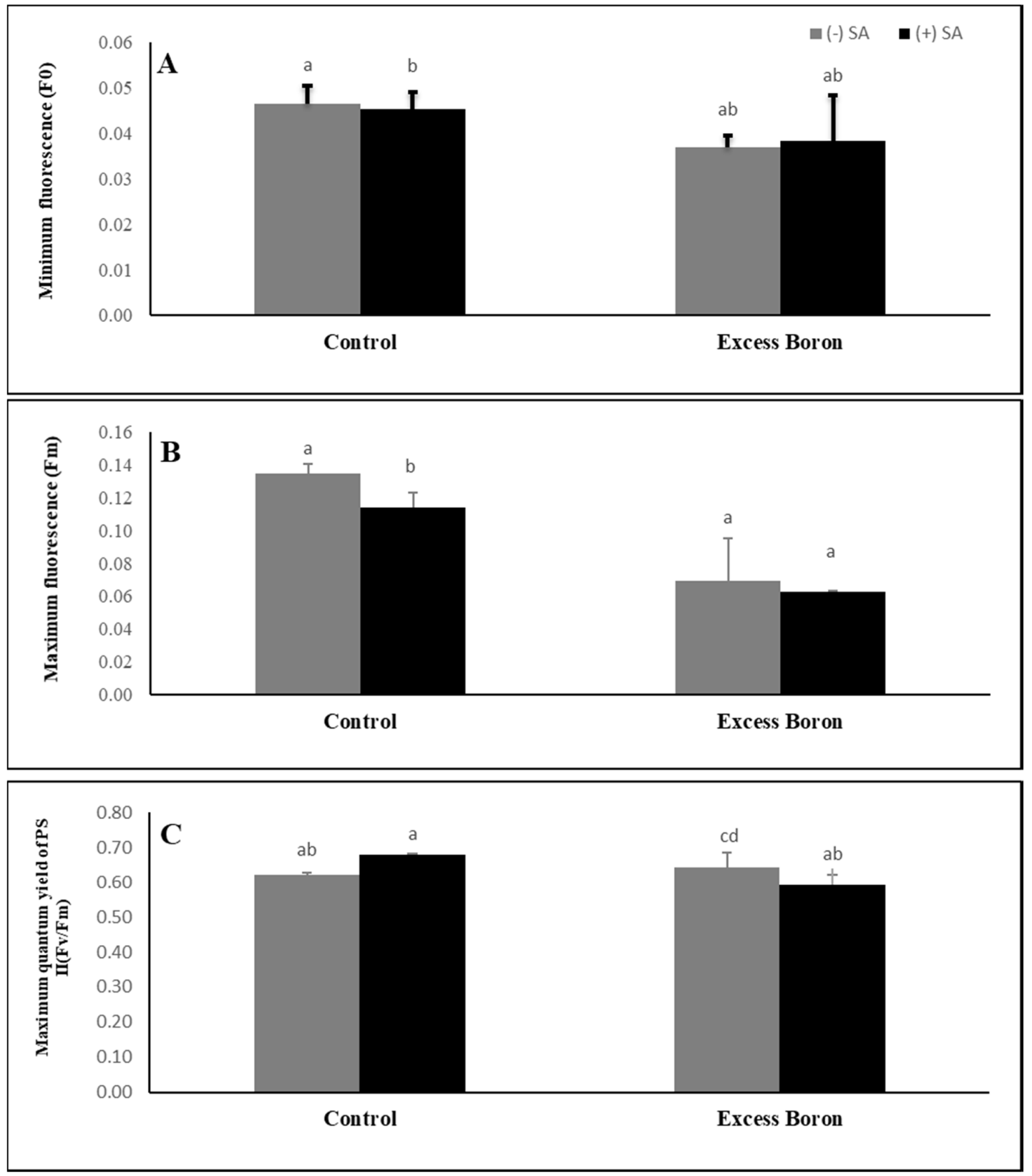

Figure 3. Effects of $0.3 \mathrm{mM} \mathrm{SA}$ on chlorophyll fluorescence under excess boron at 35 days old. (A) minimum fluorescence, (B) maximum fluorescence, and (C) maximum quantum yield. The bars stand for mean \pm SD. ANOVA were analyzed variations between the four treatments. The various letters indicate a significant difference from $p<0.05$.

\subsection{MDA Content and the Endogenous ROS Generation Rate}

A higher amount of the malondialdehyde (MDA) was recorded in boron-stressed plants as compared with the unstressed plants (Figure 4$)$. Treatment with SA $(0.3 \mathrm{mM})$ caused a significant decreased in the MDA content of watermelon leaves under control conditions and excess boron stress (Figure 4). 

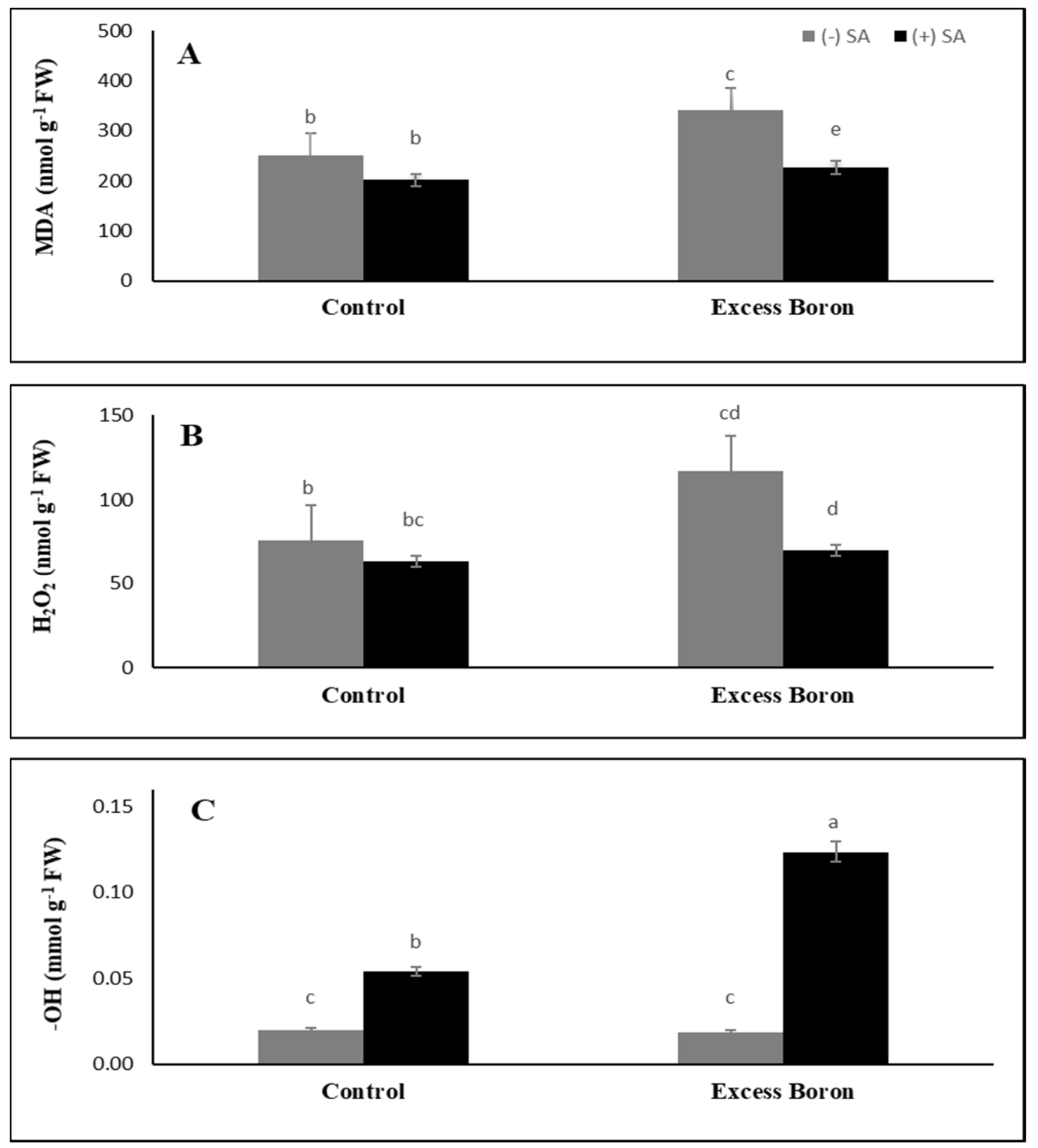

Figure 4. Effects of $0.3 \mathrm{mM}$ SA on oxidative stress parameters under excess boron at 35 days old. (A) lipid peroxidation, (B) hydrogen peroxide, and (C) extra-cellular hydroxyl radicals. The bars stand for mean \pm SD. ANOVA were analyzed variations between the four treatments. The various letters indicate a significant difference from $p<0.05$.

The generation of $\mathrm{ROS}$ such as $\mathrm{H}_{2} \mathrm{O}_{2}$ and $\mathrm{OH}^{-}$formation was determined in $\mathrm{B}$ treated watermelon leaves (Figure 3). The production of ROS molecules in watermelon leaves has increased significantly by boron excess compared to the unstressed plants. Moreover, SA significantly reduced the generation of $\mathrm{H}_{2} \mathrm{O}_{2}$ in non-B-stressed plants and stressed plants. For instance, SA more effectively reduced $\mathrm{H}_{2} \mathrm{O}_{2}$ generation in excess boron plants (Figure 4).

\subsection{Antioxidant Enzyme Activities}

The antioxidant enzymes activities (superoxide dismutase (SOD), ascorbate peroxidase (APX), peroxidase (POD), catalase (CAT), and glutathione reductase (GR) were significantly up-regulated in response to excess boron (Figure 5). The most pronounced accumulation (in POD, CAT, and APX) was detected in watermelon leaves under excess boron. SA treatments further improved the activities 
of POD, CAT, APX, and reduced glutathione (GSH) in the excess boron-stressed plants (Figure 5). In addition, SA significantly activated SOD, POD, CAT, and GSH in the control plants compared to their respective non-SA leaves (Figure 5).
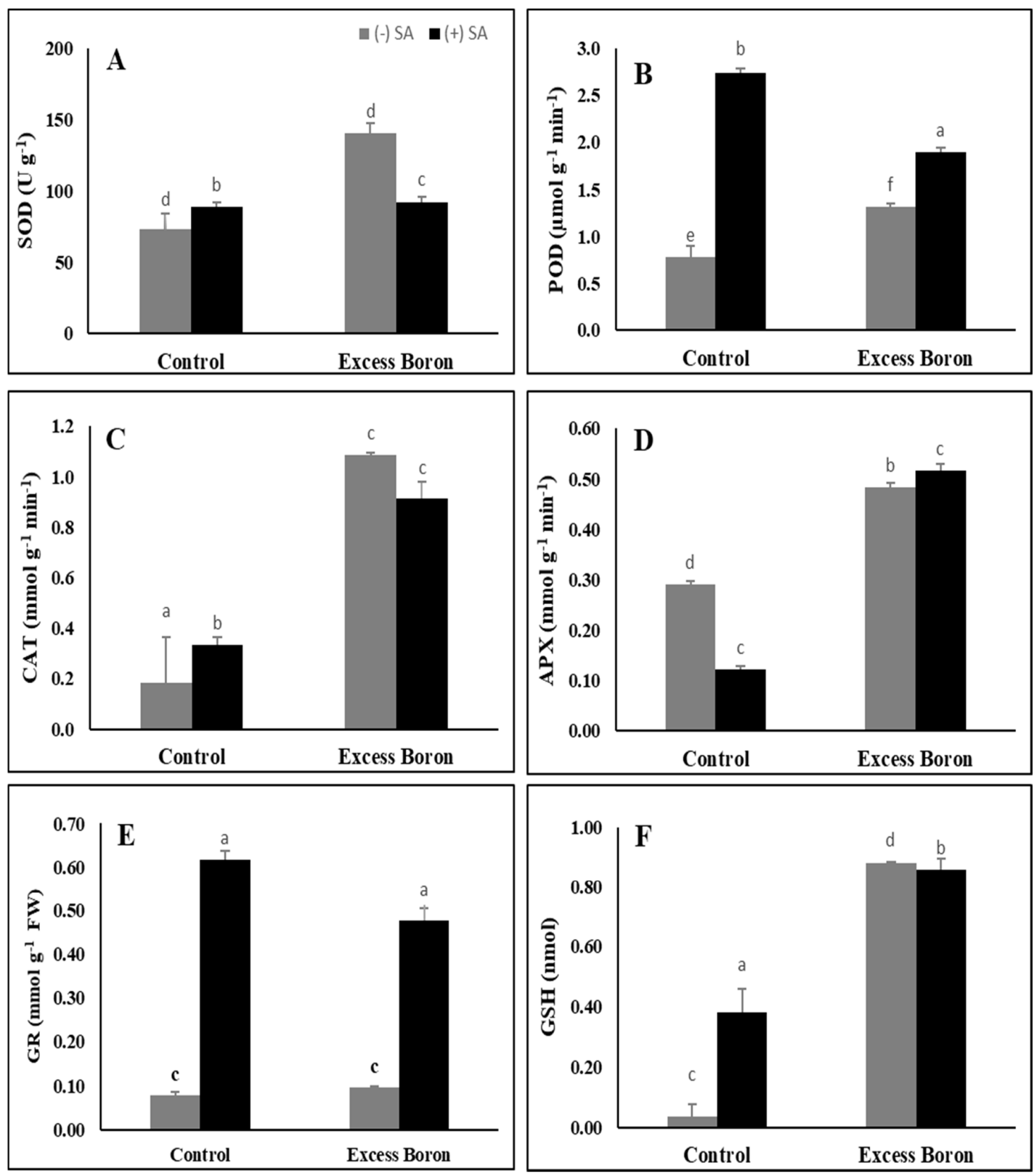

Figure 5. Effects of $0.3 \mathrm{mM}$ SA on antioxidant enzyme activities under excess boron at 35 days old. (A) superoxide dismutase, (B) peroxidase, (C) catalase, (D) ascorbic peroxidase, (E) glutathione reductase, and $(\mathbf{F})$ reduced glutathione. The bars stand for mean \pm SD. ANOVA were analyzed variations between the four treatments. The various letters indicate a significant difference from $p<0.05$.

\subsection{Total Soluble Protein (TSP) and Proline Content}

TSP in the leaves of watermelon plants showed non-significant change under excess boron compared to the untreated plants (Figure 6). The application of SA exerted non-significant effects on the TSP in watermelon leaves under excess boron. On the other hand, the amount of proline in watermelon leaves was unaffected under excess boron, while the application of SA caused a significant inhibition of proline content in plants grown under excess boron (Figure 6). 

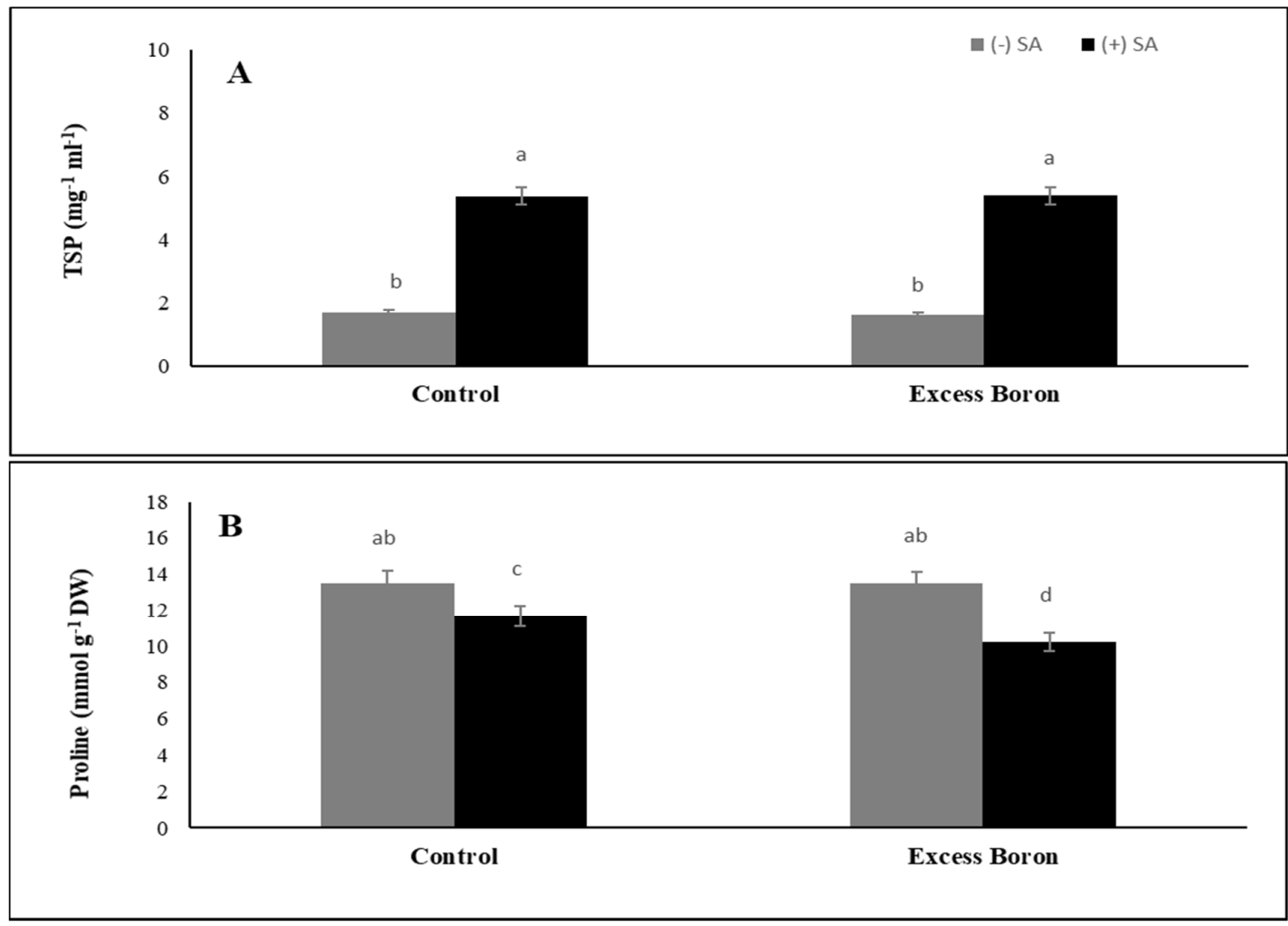

Figure 6. Effects of $0.3 \mathrm{mM}$ SA on total soluble protein (A) and proline (B) content under excess boron at 35 days old. The bars stand for mean \pm SD. ANOVA were analyzed variations between the four treatments. The various letters indicate a significant difference from $p<0.05$.

\section{Discussion}

Boron is an important mineral nutrient needed for most plant species to progress and grow adequately. Excess boron can lead to lower growth, alter photosynthetic levels and cause morphological changes in the leaves [4]. In this experiment, we observed excess boron-induced chlorophyll and carotenoid deficiency in watermelon leaves. Analogous results were recorded by Aftab et al. [43]. The chlorophyll deficiency may be due to the production of degradation enzymes such as $\delta$-aminolevulinic acid and protochlorophyllide under B stress [4]. Moreover, excess boron caused inhibition in plant growth (Table 1). The inhibition of growth in watermelon might result from the excess-boron-induced modification of essential metabolic processes, such as photosynthesis, and the nutrient uptake [4]. Furthermore, the inhibition of plant growth via excess boron may be due to the root cell division modulation and modification of the gene expression patterns associated with abscisic acid (ABA), or cell wall modifications, mitosis, water transport, and cell elongation [44,45].

The drop in photosynthetic pigments may be attributed to the accumulation of MDA and $\mathrm{H}_{2} \mathrm{O}_{2}$, resulting in the oxidation of chlorophyll and chloroplast membranes, which could be aggravated by excess B levels [4]. Treatment with SA protects photosynthetic pigments under excess boron. Some reports also indicate that $\mathrm{SA}$ is an effective photosynthesis regulator because it has a positive impact on the structure of the leaves and chloroplasts [46], as well as chlorophyll and carotenoid contents [47]. Alternatively, SA acts in the biogenesis for chloroplasts, protecting them against ROS and increasing chlorophyll stability [46]. In the present study, we observed an oxidative stress-induced reduction in the PN, Gs, and Tr of watermelon under excess boron stress (Figure 3). Similar results were reported by Lovatt et al. [5], who found that B reduced both Gs and the Pn transpiration rate.

Consequently, because of $\mathrm{CO}_{2}$ limits, PSII electrons are available from thylakoid and stromal fatty acids [48]. An SA supply significantly enhanced the Pn, Gs, and $\mathrm{Tr}$ of BD watermelon leaves compared to plants without an SA supply, which may prevent the oxidation of auxin, whose elevated 
contents increased Pn in the leaf [49]. Treatment with SA significantly decreased the PSII (Fv/Fm) of the plants under excess boron compared to their respective treatments without $\mathrm{SA}$, suggesting that the exclusion of SA induced changes in chlorophyll fluorescence, from watermelon tolerance to B stress. This inhibition in the fluorescence of chlorophyll under excess boron may be due to oxidation of chlorophyll and chloroplast membranes, which may be exacerbated by excess B, as recorded in hot pepper [50].

SA participates in the regulation of multiple biochemical processes under excess boron stress. Our results showing excess boron are contrary to those in previous studies, which showed that SA decreased boron toxicity stress $[32,33,40]$. These differences may be due to the different excess boron and SA concentrations and genetic resources used in our study. Watermelon plants translocated relatively more $B$ from the root to leaf tissues, as evidenced by the high value of the translocation factor (Table 2). Similarly, El-Feky et al. [32] found that the accumulation of B was significantly higher in barley shoots than in roots under boron toxicity [51]. SA not only reduced the stress conditions of BT by reducing the accumulation of $B$ within the plant organs, but also by reducing the distribution of root to leaf B (Table 2). These results are in agreement with the findings of El-Feky et al. [32] and El-Feky et al. [32,52] on barley tissue. SA may work through certain specific processes, such as reducing the absorption or triggering the efflux from the roots, i.e., processes leading to lower cytoplasmic $B$ content [30].

Unbalance in nutrients may result from excessive boron stress based on nutrient availability, absorption, transport and competition (Table 3). One mechanism for alleviating excess boron stress may be the shift of the mineral absorption after SA treatments. We postulate that SA lowered the damaging impacts of excess boron and enhanced the stability of the membrane and, therefore, the tolerance of the plant. In SA plants, the possible mechanism of B tolerance is the detoxification of excess B through cell exclusion and/or vacuolar compartmentalization. Furthermore, apoplast-formed B complexes could play a significant role in the excess boron tolerance of the plant. In this regard, Reid et al. [53] suggested that the transfer of B from the symplast into the apoplast or from the cytoplasm into the vacuole may facilitate plant tolerance to boron toxicity [54]. In plants, there are several reports that show excess boron stress-induced changes in the activity of both antioxidant enzymes and soluble antioxidant levels [3], accompanied by an enhancement of lipid peroxidation [55]. Excess boron can inhibit the transport of electrons and may result in the production and accumulation of ROS, such as $\mathrm{H}_{2} \mathrm{O}_{2}$ and $\mathrm{OH}^{-}$, in watermelon (Figure 4).

Moreover, SA application successfully inhibited the accumulation of MDA and the generation of $\mathrm{H}_{2} \mathrm{O}_{2}$ under excess boron stress compared to their respective SA alone. A high exogenous B supply could facilitate the transportation of boric acid to the cell, which could be partially converted to borate due to the cytosol's elevated inner $\mathrm{pH}$ [56], thus potentially releasing free ROS, such as $\mathrm{O}_{2}, \mathrm{OH}$, and $\mathrm{H}_{2} \mathrm{O}_{2}$ [8]. Similar findings were noted by [57], who clarified that $\mathrm{MDA}$ and $\mathrm{H}_{2} \mathrm{O}_{2}$ concentrations in safflower crops subjected to excess $\mathrm{Zn}$ are decreased significantly after supplementation with $\mathrm{SA}$. It has been observed that SA relieves heavy metal-induced injury through metal chelation, scavenges lipid peroxyl radicals, and prevents lipid peroxidation through the activation of the antioxidant system and is, therefore, capable of protecting membrane integrity [58-63].

The protective effect of SA towards B stress strongly correlates with severalfold increases in levels of the hydroxyl radical (OH.), the most reactive ROS (Figure 4). SA can significantly elevate OH. levels even in unstressed (normal B) plants but OH. levels increased in SA-treated plants with B stress. It is known that $\mathrm{OH}$. is mainly generated from $\mathrm{H}_{2} \mathrm{O}_{2}$ and $\mathrm{Fe}^{2+}$ via the Fenton reaction. The presence of free $\mathrm{Fe}$ is key to this process, e.g., in plants, where excess Fe is stored by ferritin proteins [64]. Therefore, it could be worth monitoring changes in Fe levels in SA-treated, B-stressed plants. Moreover, it is worth testing the effect of scavenging $\mathrm{OH}$. and/or chelating Fe on the protective action of SA.

The activities of antioxidant defense enzymes, such as SOD, APX, POD, GR, and GSH, were significantly increased in response to B stress (Figure 5). These antioxidants play a critical role in the alleviation of abiotic stresses. For instance, SOD catalyzes the dismutation of superoxide to 
$\mathrm{H}_{2} \mathrm{O}_{2}$ and $\mathrm{O}_{2}$ as a significant scavenger. However, $\mathrm{H}_{2} \mathrm{O}_{2}$ is also poisonous to cells, and must be further drained by CAT or POD or both into water and $\mathrm{O}_{2}[65,66]$. CAT and POD, when coordinated with SOD, seem to play an important protective role in scavenging ROS [67]. Our results are in agreement with those of Garcia et al. [68], who found that boron toxicity induced SOD activity in tobacco leaves. SA treatments further enhanced the activities of POD, CAT, and GR that were activated under excess boron conditions (Figure 5), suggesting that POD, CAT, and GR play a key role in the alleviation of both aspects of B stress. Similar results found that the application of SA activated antioxidant enzymes under zinc [57] and nickel stress [69].

Glutathione (GSH), a multi-functional plant metabolite, plays a significant role in oxidative stress in cell defense and safety. GSH protects thiol protein groups during stress from oxidation [70]. GSH content was significantly increased in watermelon plants under excess boron and SA treatments in stressed plants (Figure 5). Moreover, Cervilla et al. [2] found that GSH was significantly increased in only one tomato species under B stress. Yadav [71], likewise, suggested that the availability of GSH is related to the formation of phytochelatins, which are used to alleviate the toxicity of heavy metals. SA also function as an antioxidant [72], and the prevention of oxidative cell damage during stress has been suggested to be one of the stress tolerance mechanisms [73]. This level of safety was due to the increased production of antioxidants [18].

Proline content in watermelon plants showed a decrease under excess boron and control conditions after SA treatment (Figure 6). These findings are consistent with those of Namdjoyan et al. [57], who found that the addition of SA and sodium nitroprusside in Zn-stressed safflower crops caused a sharp decrease in proline content. SA's function in proline degradation may be due to enhanced proline dehydrogenase activity [69].

The total soluble protein (TSP) in the leaves of watermelon plants experienced non-significant effects under excess boron and the application of SA but increased for the SA-treated plants compared to the non-stressed and stressed plants (Figure 6) [74,75]. SA induced a considerable increase in the content of protein fractions in sunflower plants under $\mathrm{Cu}$ stress [76] and chamomile plants under $\mathrm{Cd}$ and Ni stresses [77].

\section{Materials and Methods}

\subsection{Plant Materials, Growth Conditions, and Treatments}

Watermelon seeds are sterilized and then soaked in distilled water for one day at room temperature. Then, the seeds are germinated for 5 days in the dark on filter papers. The seedlings were transplanted into $5 \mathrm{~L}$ plastic boxes containing full Hoagland, while excess boron stress was applied by adding boric acid $\left(\mathrm{H}_{3} \mathrm{BO}_{3}\right)$ into the solution at $10 \mathrm{mg} \mathrm{L}^{-1}$. The concentrations of $\mathrm{B}$ were chosen based on preliminary studies using different concentrations of $\mathrm{B}$ to choose the suitable concentrations for excess boron and according to the literature [3,4]. SA $(0.3 \mathrm{mM})$ supplementations were added to the Hoagland solution directly after transplanting into the plastic boxes. In our experiments, we used 2 concentrations of $B$ and 2 concentrations of SA (4 treatments). Each treatment used 30 plants divided into three boxes (10 plants for each box). The plants grew for 30 days in growth chambers under $20-25 / 15-20{ }^{\circ} \mathrm{C}$ (day/night) and $60 \%$ humidity. The solutions were changed twice a week, and the $\mathrm{pH}$ of the solution was preserved between at 6.0 and 6.3 .

Leaves from the third middle part were used for photosynthetic gas exchange and biochemical aspects.

\subsection{Morphological Measurements}

Following 1 month of the treatments, 10 seedlings were harvested from each treatment. The plants were dried out at $80^{\circ} \mathrm{C}$ for 3 days. The root system, including surface areas, root volume, root diameter, and the number of root tips, was analyzed with WinRhizo Pro (S) v. 2009a software, in accordance with Yu et al. [78]. 


\subsection{Determination of $B$ and Uptake of Other Nutrients}

The dried shoot and root samples were digested in a mixture of nitric acid and hydrogen peroxide at $130{ }^{\circ} \mathrm{C}$. Mineral concentrations of $\mathrm{B}, \mathrm{Ca}^{2+}, \mathrm{Mg}^{2+}, \mathrm{K}^{+}$, and $\mathrm{Na}^{+}$were assayed by coupled plasma mass spectrometry (ICP-MS, Agilent 7500a, Agilent Technologies, Santa Clara, CA, USA) [79].

\subsection{Malondialdehyde (MDA) and Reactive Oxygen Species (ROS)}

Lipid peroxidation was measured by malondialdehyde (MDA), according to Zhou et al. [80].

Hydrogen peroxide was measured via the method described by Yordanov et al. [81] with a slight modification. The absorbance was read at $630 \mathrm{~nm}$ after $15 \mathrm{~min}$.

Extra-cellular hydroxyl radicals $(\mathrm{OHs})$ from the leaf samples were estimated following the protocol of Halliwell et al. [82]. The reaction mixtures contained, in a final volume of $1.0 \mathrm{~mL}$, the following reagents at the following concentrations: deoxyribose (variable concentration), $\mathrm{KH}_{2} \mathrm{PO}_{4}-\mathrm{KOH}$ buffer, pH $7.4(20 \mathrm{mM}), \mathrm{FeCl}_{3}(100 \mu \mathrm{M})$, EDTA $(104 \mu \mathrm{M}), \mathrm{H}_{2} \mathrm{O}_{2}(1 \mathrm{mM})$, and ascorbate $(100 \mu \mathrm{M})$. Solutions of $\mathrm{FeC}_{3}$ and ascorbate were produced immediately before use in deaerated water. Reaction mixtures were incubated at $37^{\circ} \mathrm{C}$ for $1 \mathrm{~h}$, and the color was developed at $532 \mathrm{~nm}$ using a spectrophotometer.

\subsection{Chlorophyll and Carotenoid Determination}

Fresh leaf tissues were ground in the presence of liquid nitrogen. Methanol (95\%) was added to the samples, and the mixture was centrifuged for $5 \mathrm{~min}$ at $4500 \mathrm{rpm}$ at $20^{\circ} \mathrm{C}$. The absorbance of the extracted solution was recorded at wavelengths of 470,649 and $665 \mathrm{~nm}$ to estimate the chlorophyll-a, chlorophyll-b [83], and carotenoids [84] using a spectrophotometer (Shimadzu UV-1700, Tokyo, Japan).

\subsection{Photosynthetic Gas Exchange Parameters}

The photosynthetic rate (Pn), stomatal conductance (Gs), transpiration rate (Tr), and intercellular $\mathrm{CO}_{2}$ were recorded using a portable LI-COR 6400 photosynthesis system (Lincoln, NE, USA). The intrinsic water use efficiency (WUE) was calculated from the ratio of the photosynthesis rate and stomatal conductance [84].

\subsection{Chlorophyll Fluorescence}

The maximal quantum yield of PSII (Fv/Fm), initial fluorescence (F0), and maximum fluorescence (Fm) were determined by an imaging pulse amplitude modulation (PAM) device (IMAG-MAXI; Heinz Walz, Effeltrich, Germany).

\subsection{Antioxidant Enzymes}

Fresh leaf samples $(0.5 \mathrm{~g})$ (4 replicates in total) were homogenized in cold phosphate buffer (pH 7.8). The homogenate was centrifuged at $13,000 \times g$ for $20 \mathrm{~min}$ at $4{ }^{\circ} \mathrm{C}$, and the supernatant was used to determine the enzymatic activities.

Superoxide dismutase activity (SOD: EC 1.15.1.1) was determined following the method of Zhang et al. [85]. One unit of SOD was defined as the amount contained in the volume of extract that caused a 50\% inhibition of the SOD-inhibitable fraction of the Nitro blue tetrazolium (NBT) reduction.

Peroxidase activity (POD: EC 1.11.1.7) was assayed according to Velikova et al. [86]. The absorbance was recorded at $470 \mathrm{~nm}$.

Catalase activity (CAT: EC 1.11.1.6) was measured according to Aebi [87]. The consumption of $\mathrm{H}_{2} \mathrm{O}_{2}$ was monitored using a spectrophotometer at $240 \mathrm{~nm}\left(\mathrm{e}=39.4 \mathrm{mM}^{-1} \cdot \mathrm{cm}^{-1}\right)$ for $3 \mathrm{~min}$.

Ascorbate peroxidase activity (APX: EC 1.11.1.11) was estimated by the method of Nakano et al. [88]. The absorbance was read at $265 \mathrm{~nm}\left(\mathrm{e}=13.7 \mathrm{mM}^{-1} \cdot \mathrm{cm}^{-1}\right)$.

Glutathione reductase (GR: EC 1.6.4.2) activity was assayed according to Jiang et al. [89] after the oxidation of NADPH at $340 \mathrm{~nm}$ (with an extinction coefficient of $6.2 \mathrm{mM} \cdot \mathrm{cm}^{-1}$ ) for $1 \mathrm{~min}$. Reduced 
glutathione (GSH) was determined according to Law et al. [90]. An increase in the absorbance at $412 \mathrm{~nm}$ was measured after the addition of 5,5-dithiobis (2-nitrobenzoic acid) (DTNB).

\subsection{Total Soluble Protein and Proline}

Total soluble protein (TSP) was determined according to the Bradford [91] method using bovine serum albumin as a standard. For proline determination, sulphosalicylic acid methods are being applied and the absorbance was recorded at $520 \mathrm{~nm}$ using a spectrophotometer [92].

\subsection{Statistical Analysis}

A completely randomized block design was used in our study, and the biostatistics were analyzed using CoStatv. 6.4 software. The results are denoted as the mean \pm SD.

\section{Conclusions}

The present work demonstrates that SA can alleviate excess boron. The mechanisms by which SA alleviates excess boron mainly involve the following activities: (1) promoting chlorophyll content, (2) modulating the balance of mineral elements, (3) protecting against oxidative stress by decreasing MDA and ROS production, and (4) acting directly as an antioxidant to scavenge reactive oxygen species and/or indirectly modulating redox balance through the activation of the antioxidant responses. Our results could facilitate an integrated and optimized management strategy to alleviate excess boron in watermelon, but further study is needed.

Author Contributions: Conceptulazation, M.M.-F., A.M., M.C., S.A.; formal analysis, M.M.-F., H.I.M., A.M., A.E., M.C., S.A.; data analysis, M.M.-F., M.Z., H.I.M., A.E.; K.M.G., M.K., S.A., H.I.M., A.E.; resources, H.I.M., A.N.M., K.M.G., M.Z.; supervision, A.E., K.M.G., M.Z.; visualization, H.I.M., A.M., A.E., A.N.M., K.M.G., M.C., S.A., M.Z.; funding, M.M.-F., A.N.M., K.M.G., M.C., S.A.; writing the manuscript, M.M.-F., H.I.M., A.E.; editing the revised version, A.M., A.N.M., M.Z. All authors have read and agreed to the published version of the manuscript.

Funding: This work was supported by the earmarked fund for Modern Agro-Industry Technology Research System (CARS-26-17) of China, the National Key Technology R\&D Program of China (2011BAD12B04), National Natural Science Foundation of China (31372077), Science and Technology Program of Zhejiang Province (2011C12001) and key science and technology breeding program of agricultural new variety of Zhejiang Province (2012C129031-2-11).

Acknowledgments: We would like to thank my group team in Guangdong Academy of Agricultural Sciences; Linfeng Li, Yichun Li, Mingdeng Tang and Yanhong Wang for their support and cooperation during the writing of this article. Moreover, we would like to thank Muhammad Dawood, Basharat Ali and Tariq Rafique for their support during biochemical analyses of the manuscript.

Conflicts of Interest: The authors state that no conflict of interest exists.

\section{References}

1. Tanaka, M.; Fujiwara, T. Physiological roles and transport mechanisms of boron: Perspectives from plants. Pflügers Arch. Eur. J. Physiol. 2008, 456, 671-677. [CrossRef] [PubMed]

2. Cervilla, L.M.; Blasco, B.; RÍOs, J.J.; Romero, L.; Ruiz, J.M. Oxidative stress and antioxidants in tomato (solanum lycopersicum) plants subjected to boron toxicity. Ann. Bot. 2007, 100, 747-756. [CrossRef]

3. Moustafa-Farag, M.; Bingsheng, F.; Malangisha Guy, K.; Hu, Z.; Yang, J.; Zhang, M. Activated antioxidant enzymes-reduced malondialdehyde concentration, and improved mineral uptake-promoted watermelon seedlings growth under boron deficiency. J. Plant Nutr. 2016, 39, 1989-2001. [CrossRef]

4. Moustafa-Farag, M.; Najeeb, U.; Yang, J.; Hu, Z.; Fang, Z.M. Nitric oxide protects carbon assimilation process of watermelon from boron-induced oxidative injury. Plant Physiol. Biochem. 2017, 111, 166-173. [CrossRef] [PubMed]

5. Lovatt, C.J.; Bates, L.M. Early effects of excess boron on photosynthesis and growth of Cucurbita pepo. J. Exp. Bot. 1984, 35, 297-305. [CrossRef]

6. Ardic, M.; Sekmen, A.H.; Turkan, I.; Tokur, S.; Ozdemir, F. The effects of boron toxicity on root antioxidant systems of two chickpea (Cicer arietinum L.) cultivars. Plant Soil 2009, 314, 99-108. [CrossRef] 
7. Roldán, M.; Belver, A.; Rodríguez-Rosales, P.; Ferrol, N.; Donaire, J.P. In vivo and in vitro effects of boron on the plasma membrane proton pump of sunflower roots. Physiol. Plant. 1992, 84, 49-54. [CrossRef]

8. Choi, E.Y.; Kolesik, P.; McNeill, A.N.N.; Collins, H.; Zhang, Q.; Huynh, B.L.; Graham, R.; Stangoulis, J. The mechanism of boron tolerance for maintenance of root growth in barley (Hordeum vulgare L.). Plant Cell Environ. 2007, 30, 984-993. [CrossRef]

9. Ghanati, F.; Morita, A.; Yokota, H. Induction of suberin and increase of lignin content by excess boron in tobacco cells. Soil Sci. Plant Nutr. 2002, 48, 357-364. [CrossRef]

10. Senousy, H.H.; Abd Ellatif, S.; Ali, S. Assessment of the antioxidant and anticancer potential of different isolated strains of cyanobacteria and microalgae from soil and agriculture drain water. Environ. Sci. Pollut. Res. 2020, 27, 18463-18474. [CrossRef]

11. Vwioko, E.; Adinkwu, O.; El-Esawi, M.A. Comparative Physiological, Biochemical, and Genetic Responses to Prolonged Waterlogging Stress in Okra and Maize Given Exogenous Ethylene Priming. Front. Physiol. 2017, 8, 632. [CrossRef]

12. Mohamed, H.I.; Elsherbiny, E.A.; Abdelhamid, M.T. Physiological and biochemical responses of Vicia faba plants to foliar application with zinc and iron. Gesunde Pflanzen 2016, 68, 201-212. [CrossRef]

13. El-Esawi, M.A.; Alaraidh, I.A.; Alsahli, A.A.; Alzahrani, S.M.; Ali, H.M.; Alayafi, A.A.; Ahmad, M. Serratia liquefaciens KM4 Improves Salt Stress Tolerance in Maize by Regulating Redox Potential, Ion Homeostasis, Leaf Gas Exchange and Stress-Related Gene Expression. Int. J. Mol. Sci. 2018, 19, 3310. [CrossRef]

14. Elkelish, A.A.; Soliman, M.H.; Alhaithloul, H.A.; El-Esawi, M.A. Selenium protects wheat seedlings against salt stress-mediated oxidative damage by up-regulating antioxidants and osmolytes metabolism. Plant Physiol. Biochem. 2019, 137, 144-153. [CrossRef]

15. Abdelaal, K.A.; EL-Maghraby, L.M.; Elansary, H.; Hafez, Y.M.; Ibrahim, E.I.; El-Banna, M.; El-Esawi, M.; Elkelish, A. Treatment of sweet pepper with stress tolerance-inducing compounds alleviates salinity stress oxidative damage by mediating the physio-biochemical activities and antioxidant systems. Agronomy 2020, 10, 26. [CrossRef]

16. Loake, G.; Grant, M. Salicylic acid in plant defence-The players and protagonists. Curr. Opin. Plant Biol. 2007, 10, 466-472. [CrossRef]

17. Taşgín, E.; Atící, Ö.; Nalbantoğlu, B. Effects of salicylic acid and cold on freezing tolerance in winter wheat leaves. Plant Growth Regul. 2003, 41, 231-236. [CrossRef]

18. El-Esawi, M.A.; Alayafi, A.A. Overexpression of Rice Rab7 Gene Improves Drought and Heat Tolerance and Increases Grain Yield in Rice (Oryza sativa L.). Genes 2019, 10, 56. [CrossRef]

19. Elkelish, A.; Qari, S.H.; Mazrou, Y.S.A.; Abdelaal, K.A.A.; Hafez, Y.M.; Abu-Elsaoud, A.M.; Batiha, G.E.-S.; El-Esawi, M.A.; El Nahhas, N. Exogenous Ascorbic Acid Induced Chilling Tolerance in Tomato Plants Through Modulating Metabolism, Osmolytes, Antioxidants, and Transcriptional Regulation of Catalase and Heat Shock Proteins. Plants 2020, 9, 431. [CrossRef]

20. El-Esawi, M.A.; Al-Ghamdi, A.A.; Ali, H.M.; Alayafi, A.A. Azospirillum lipoferum FK1 confers improved salt tolerance in chickpea (Cicer arietinum L.) by modulating osmolytes, antioxidant machinery and stress-related genes expression. Environ. Exp. Bot. 2019, 159, 55-65. [CrossRef]

21. Sharma, Y.K.; León, J.; Raskin, I.; Davis, K.R. Ozone-Induced Responses in Arabidopsis thaliana: The Role of Salicylic Acid in the Accumulation of Defense-Related Transcripts and Induced Resistance. Proc. Natl. Acad. Sci. USA 1996, 93, 5099-5104. [CrossRef] [PubMed]

22. Elkeilsh, A.; Awad, Y.M.; Soliman, M.H.; Abu-Elsaoud, A.; Abdelhamid, M.T.; El-Metwally, I.M. Exogenous application of $\beta$-sitosterol mediated growth and yield improvement in water-stressed wheat (Triticum aestivum) involves up-regulated antioxidant system. J. Plant Res. 2019, 132, 881-901. [CrossRef] [PubMed]

23. Metwally, A.; Finkemeier, I.; Georgi, M.; Dietz, K.-J. Salicylic acid alleviates the cadmium toxicity in barley seedlings. Plant Physiol. 2003, 132, 272-281. [CrossRef]

24. Palma, J.M.; Sandalio, L.M.; Javier Corpas, F.; Romero-Puertas, M.C.; McCarthy, I.; del Río, L.A. Plant Proteases, Protein Degradation, and Oxidative Stress: Role of Peroxisomes; Elsevier Masson SAS: Paris, France, 2002; Volume 40, pp. 521-530.

25. Drazic, G.; Mihailovic, N. Modification of cadmium toxicity in soybean seedlings by salicylic acid. Plant Sci. 2005, 168, 511-517. [CrossRef] 
26. Li, Q.; Wang, Y.; Wang, G.; Yang, D.; Guan, C.; Ji, J. Foliar application of salicylic acid alleviate the cadmium toxicity by modulation the reactive oxygen species in potato. Ecotoxicol. Environ. Saf. 2019, 172, 317-325. [CrossRef] [PubMed]

27. Moradkhani, S.; Nejad, R.A.K.; Dilmaghani, K.; Chaparzadeh, N. Salicylic acid decreases Cd toxicity in sunflower plants. Ann. Biol. Res. 2013, 4, 135-141.

28. Shi, Q.; Zhu, Z. Effects of exogenous salicylic acid on manganese toxicity, element contents and antioxidative system in cucumber. Environ. Exp. Bot. 2008, 63, 317-326. [CrossRef]

29. Zhou, Z.S.; Guo, K.; Elbaz, A.A.; Yang, Z.M. Salicylic acid alleviates mercury toxicity by preventing oxidative stress in roots of Medicago sativa. Environ. Exp. Bot. 2009, 65, 27-34. [CrossRef]

30. Metwally, A.M.; Radi, A.A.; El-Shazoly, R.M.; Hamada, A.M. The role of calcium, silicon and salicylic acid treatment in protection of canola plants against boron toxicity stress. J. Plant Res. 2018, 131, 1015-1028. [CrossRef]

31. Saleem, M.H.; Ali, S.; Rehman, M.; Rana, M.S.; Rizwan, M.; Kamran, M.; Imran, M.; Riaz, M.; Soliman, M.H.; Elkelish, A.; et al. Influence of phosphorus on copper phytoextraction via modulating cellular organelles in two jute (Corchorus capsularis L.) varieties grown in a copper mining soil of Hubei Province, China. Chemosphere 2020, 248, 126032. [CrossRef]

32. El-Feky, S.S.; El-Shintinawy, F.A.; Shaker, E.M.; El-Din, H.A.S. Effect of elevated boron concentrations on the growth and yield of barley (hordeum vulgare 1.) and alleviation of its toxicity using different plant growth modulators. Aust. J. Crop Sci. 2012, 6, 1687-1695.

33. El-Shazoly, R.M.; Metwally, A.A.; Hamada, A.M. Salicylic acid or thiamin increases tolerance to boron toxicity stress in wheat. J. Plant Nutr. 2019, 42, 702-722. [CrossRef]

34. Eraslan, F.; Inal, A.; Pilbeam, D.J.; Gunes, A. Interactive effects of salicylic acid and silicon on oxidative damage and antioxidant activity in spinach (Spinacia oleracea L. cv. Matador) grown under boron toxicity and salinity. Plant Growth Regul. 2008, 55, 207-219. [CrossRef]

35. Chen, W.; Singh, K.B. The auxin, hydrogen peroxide and salicylic acid induced expression of the Arabidopsis GST6 promoter is mediated in part by an ocs element. Plant J. 1999, 19, 667-677. [CrossRef] [PubMed]

36. Wang, Y.-S.; Wang, J.; Yang, Z.-M.; Wang, Q.-Y.; Lü, B.; Li, S.-Q.; Lu, Y.-P.; Wang, S.-H.; Sun, X. Salicylic acid modulates aluminum-induced oxidative stress in roots of Cassia tora. Acta Bot. Sin. 2004, 46, 819-828.

37. He, Y.; Liu, Y.; Cao, W.; Huai, M.; Xu, B.; Huang, B. Effects of Salicylic Acid on Heat Tolerance Associated with Antioxidant Metabolism in Kentucky Bluegrass. Crop Sci. 2005, 45, 988-995. [CrossRef]

38. Wang, L.-J.; Li, S.-H. Thermotolerance and Related Antioxidant Enzyme Activities Induced by Heat Acclimation and Salicylic Acid in Grape (Vitis vinifera L.) Leaves. Plant Growth Regul. 2006, 48, 137-144. [CrossRef]

39. Gholamnezhad, J.; Sanjarian, F.; Goltapeh, E.M.; Safaie, N.; Razavi, K. Effect of Salicylic Acid on Enzyme Activity in Wheat in Immediate Early Time after Infection with Mycosphaerella Graminicola. Sci. Agric. Bohem. 2016, 47, 1-8. [CrossRef]

40. Muhammad, A.J.; Shaheed, A.I. Effects of salicylic acid and silicon on oxidative damage and antioxidant activity in mung bean cuttings under boron toxicity. J. Univ. Babylon 2012, 22, 335-348.

41. Ozturk, M.; Sakcali, S.; Gucel, S.; Tombuloglu, H. Boron and Plants. In Plant Adaptation and Phytoremediation; Ashraf, M., Ozturk, M., Ahmad, M.S.A., Eds.; Springer: Dordrecht, The Netherlands, 2010; pp. $275-311$. [CrossRef]

42. Liu, Z.; Zhu, Q.Q.; Tong, L.H. Boron-deficient soils and their distribution in China. Acta Pedol. Sin. 1980, 17, 228-239.

43. Aftab, T.; Khan, M.M.A.; Naeem, M.; Idrees, M.; Moinuddin; Teixeira da Silva, J.A.; Ram, M. Exogenous nitric oxide donor protects Artemisia annua from oxidative stress generated by boron and aluminium toxicity. Ecotoxicol. Environ. Saf. 2012, 80, 60-68. [CrossRef] [PubMed]

44. Aquea, F.; Federici, F.; Moscoso, C.; Vega, A.; Jullian, P.; Haseloff, J.I.M.; Arce-Johnson, P. A molecular framework for the inhibition of Arabidopsis root growth in response to boron toxicity. Plant Cell Environ. 2012, 35, 719-734. [CrossRef] [PubMed]

45. Josten, P.; Kutschera, U. The Micronutrient Boron Causes the Development of Adventitious Roots in Sunflower Cuttings. Ann. Bot. 1999, 84, 337-342. [CrossRef]

46. Uzunova, A.N.; Popova, L.P. Effect of Salicylic Acid on Leaf Anatomy and Chloroplast Ultrastructure of Barley Plants. Photosynthetica 2000, 38, 243-250. [CrossRef] 
47. Fariduddin, Q.; Hayat, S.; Ahmad, A. Salicylic Acid Influences Net Photosynthetic Rate, Carboxylation Efficiency, Nitrate Reductase Activity, and Seed Yield in Brassica juncea. Photosynthetica 2003, 41, 281-284. [CrossRef]

48. Moustafa-Farag, M.; Almoneafy, A.; Mahmoud, A.; Elkelish, A.; Arnao, M.B.; Li, L.; Ai, S. Melatonin and Its Protective Role against Biotic Stress Impacts on Plants. Biomolecules 2020, 10, 54. [CrossRef]

49. Arteca, R.N. Plant Growth Substances: Principles and Applications; Chapman \& Hall: New York, NY, USA, 1996.

50. Supanjani, S.; Lee, K.D. Hot pepper response to interactive effects of salinity and boron. Plant Soil Environ. 2006, 52, 227-233. [CrossRef]

51. Reid, R. Physiology and Metabalism of Boron in Plants. In Advances in Plant and Animal Boron Nutrition; Springer: Dordrecht, The Netherlands, 2007; pp. 83-90.

52. El-Feky, S.S.; El-Feky, S.S.; El-Shintinawy, F.A.; Shaker, E.M. Role of CaCl2 and salicylic acid on metabolic activities and productivity of boron stressed barley (Hordeum vulgare L.). Int. J. Curr. Microbiol Appl. Sci. 2014, 3, 368-380.

53. Reid, R.; Fitzpatrick, K. Influence of Leaf Tolerance Mechanisms and Rain on Boron Toxicity in Barley and Wheat. Plant Physiol. 2009, 151, 413-420. [CrossRef]

54. Pang, Y.; Li, L.; Ren, F.; Lu, P.; Wei, P.; Cai, J.; Xin, L.; Zhang, J.; Chen, J.; Wang, X. Overexpression of the tonoplast aquaporin AtTIP5;1 conferred tolerance to boron toxicity in Arabidopsis. J. Genet. Genom. 2010, 37, 389-397. [CrossRef]

55. Karabal, E.; Yücel, M.; Öktem, H.A. Antioxidant responses of tolerant and sensitive barley cultivars to boron toxicity. Plant Sci. 2003, 164, 925-933. [CrossRef]

56. Wimmer, M.A.; Mühling, K.H.; LÄuchli, A.; Brown, P.H.; Goldbach, H.E. Boron Toxicity: The Importance of Soluble Boron. In Boron in Plant and Animal Nutrition; Goldbach, H.E., Brown, P.H., Rerkasem, B., Thellier, M., Wimmer, M.A., Bell, R.W., Eds.; Springer: Boston, MA, USA, 2002; pp. 241-253. [CrossRef]

57. Namdjoyan, S.; Kermanian, H.; Soorki, A.A.; Modarres Tabatabaei, S.; Elyasi, N. Effects of exogenous salicylic acid and sodium nitroprusside on $\alpha$-tocopherol and phytochelatin biosynthesis in zinc-stressed safflower plants. Turk. J. Bot. 2018, 42, 271-279. [CrossRef]

58. Soliman; Alhaithloul; Hakeem; Alharbi; El-Esawi; Elkelish Exogenous Nitric Oxide Mitigates Nickel-Induced Oxidative Damage in Eggplant by Upregulating Antioxidants, Osmolyte Metabolism, and Glyoxalase Systems. Plants 2019, 8, 562. [CrossRef] [PubMed]

59. Szalai, G.; Krantev, A.; Yordanova, R.; Popova, L.P.; Janda, T. Influence of salicylic acid on phytochelatin synthesis in Zea mays during Cd stress. Turk. J. Bot. 2013, 37, 708-714. [CrossRef]

60. Fodor, J.; Gullner, G.; Adam, A.L.; Barna, B.; Kömives, T.; Kiràly, Z. Local and systemic responses of antioxidants to tobacco mosaic virus infection and to salicylic acid in tobacco. Plant Physiol 1997, 114, 1443-1451. [CrossRef] [PubMed]

61. Király, Z.; Barna, B.; Kecskés, A.; Fodor, J. Down-regulation of antioxidative capacity in a transgenic tobacco which fails to develop acquired resistance to necrotization caused by tobacco mosaic virus. Free. Radic. Res. 2002, 36, 981-991. [CrossRef] [PubMed]

62. Janda, T.; Lejmel, M.A.; Molnár, A.B.; Majláth, I.; Pál, M.; Nguyen, Q.T.; Nguyen, N.T.; Le, V.N.; Szalai, G. Interaction between elevated temperature and different types of Na-salicylate treatment in Brachypodium dystachion. PLoS ONE 2020, 15, e227608. [CrossRef] [PubMed]

63. Janda, T.; Szalai, G.; Tari, I.; Paldi, E. Hydroponic treatment with salicylic acid decreases the effect of chilling injury in maize (Zea mays L.) plants. Planta 1999, 208, 175-180. [CrossRef]

64. Deák, M.; Horváth, G.V.; Davletova, S.; Török, K.; Sass, L.; Vass, I.; Barna, B.; Király, Z.; Dudits, D. Plants ectopically expressing the ironbinding protein, ferritin, are tolerant to oxidative damage and pathogens. Nat. Biotechnol. 1999, 17, 192-196. [CrossRef]

65. Mohamed, H.I. Molecular and biochemical studies on the effect of gamma rays on lead toxicity in cowpea (Vigna sinensis) plants. Biol Trace Elem Res 2011, 144, 1205-1218. [CrossRef]

66. Horváth, E.; Szalai, G.; Janda, T. Induction of abiotic stress tolerance by salicylic acid signaling. J. Plant Growth Regul. 2007, 26, 290-300. [CrossRef]

67. Jaleel, C.A.; Manivannan, P.; Wahid, A.; Farooq, M.; Al-Juburi, H.J.; Somasundaram, R.; Panneerselvam, R. Drought stress in plants: A review on morphological characteristics and pigments composition. Int. J. Agric. Biol. 2009, 11, 100-105. 
68. Garcia, P.C.; Rivero, R.M.; López-Lefebre, L.R.; Sánchez, E.; Ruiz, J.M.; Romero, L. Response of oxidative metabolism to the application of carbendazim plus boron in tobacco. Aust. J. Plant Physiol. 2001, 28, 801-806. [CrossRef]

69. Kazemi, N.; Khavari-Nejad, R.A.; Fahimi, H.; Saadatmand, S.; Nejad-Sattari, T. Effects of exogenous salicylic acid and nitric oxide on lipid peroxidation and antioxidant enzyme activities in leaves of Brassica napus L. under nickel stress. Sci. Hortic. 2010, 126, 402-407. [CrossRef]

70. Noctor, G.; Gomez, L.; Vanacker, H.; Foyer, C.H. Interactions between biosynthesis, compartmentation and transport in the control of glutathione homeostasis and signalling. J. Exp. Bot. 2002, 53, 1283-1304. [CrossRef]

71. Yadav, S.K. Heavy metals toxicity in plants: An overview on the role of glutathione and phytochelatins in heavy metal stress tolerance of plants. South Afr. J. Bot. 2010, 76, 167-179. [CrossRef]

72. Cheng, I.F.; Zhao, C.P.; Amolins, A.; Galazka, M.; Doneski, L. A hypothesis for the in vivo antioxidant action of salicyclic acid. Biometals 1996, 9, 285-290. [CrossRef]

73. El-Beltagi, H.S.; Mohamed, H.I. Reactive oxygen species, lipid peroxidation and antioxidative defense mechanism. Notulae Botanicae Horti Agrobotanici ClujNapoca. 2013, 41, 44-57. [CrossRef]

74. Akladious, S.A.; Mohamed, H.I. Physiological role of exogenous nitric oxide in improving performance, yield and some biochemical aspects of sunflower plant under zinc stress. Acta Biol. Hung. 2017, 68, 101-114. [CrossRef]

75. Mohamed, H.I.; Latif, H.H.; Hanafy, R.S. Influence of Nitric Oxide Application on Some Biochemical Aspects, Endogenous Hormones, Minerals and Phenolic Compounds of Vicia faba Plant Grown under Arsenic Stress. Gesunde Pflanzen 2016, 68, 99-107. [CrossRef]

76. El-Tayeb, M.A.; El-Enany, A.E.; Ahmed, N.L. Salicylic acid-induced adaptive response to copper stress in sunflower (Helianthus annuus L.). Plant Growth Regul. 2006, 50, 191-199. [CrossRef]

77. Kováčik, J.; Grúz, J.; Hedbávný, J.; Klejdus, B.; Strnad, M. Cadmium and Nickel Uptake Are Differentially Modulated by Salicylic Acid in Matricaria chamomilla Plants. J. Agric. Food Chem. 2009, 57, 9848-9855. [CrossRef]

78. Yu, M.; Shen, R.; Xiao, H.; Xu, M.; Wang, H.; Wang, H.; Zeng, Q.; Bian, J. Boron alleviates aluminum toxicity in pea (Pisum sativum). Plant Soil 2009, 314, 87-98. [CrossRef]

79. Wu, C.-y.; Lu, L.-1.; Yang, X.-e.; Feng, Y.; Wei, Y.-y.; Hao, H.-1.; Stoffella, P.J.; He, Z.-1. Uptake, Translocation, and Remobilization of Zinc Absorbed at Different Growth Stages by Rice Genotypes of Different Zn Densities. J. Agric. Food Chem. 2010, 58, 6767-6773. [CrossRef] [PubMed]

80. Zhou, W.; Leul, M. Uniconazole-induced alleviation of freezing injury in relation to changes in hormonal balance, enzyme activities and lipid peroxidation in winter rape. Plant Growth Regul. 1998, 26, 41-47. [CrossRef]

81. Yordanov, I.; Velikova, V.; Tsonev, T. Plant Responses to Drought, Acclimation, and Stress Tolerance. Photosynthetica 2000, 38, 171-186. [CrossRef]

82. Halliwell, B.; Gutteridge, J.M.C.; Aruoma, O.I. The deoxyribose method: A simple "test-tube" assay for determination of rate constants for reactions of hydroxyl radicals. Anal. Biochem. 1987, 165, 215-219. [CrossRef]

83. Vernon, L.P.; Seely, R.G. The Chlorophylls; Academic Press: New York, NY, USA, 1966.

84. Lichtenthaler, H.K. Chlorophylls and carotenoids: Pigments of photosynthetic biomembranes. Methods Enzymol. 1987, 148, 350-382.

85. Zhang, W.F.; Zhang, F.; Raziuddin, R.; Gong, H.J.; Yang, Z.M.; Lu, L.; Ye, Q.F.; Zhou, W.J. Effects of 5-aminolevulinic acid on oilseed rape seedling growth under herbicide toxicity stress. J. Plant Growth Regul. 2008, 27, 159-169. [CrossRef]

86. Velikova, V.; Yordanov, I.; Edreva, A. Oxidative stress and some antioxidant systems in acid rain-treated bean plants: Protective role of exogenous polyamines. Plant Sci. 2000, 151, 59-66. [CrossRef]

87. Aebi, H. Catalase in vitro. Methods Enzymol. 1984, 105, 121-126. [PubMed]

88. Nakano, Y.; Asada, K. Hydrogen peroxide is scavenged by ascorbate-specific peroxidase in spinach chloroplasts. Plant Cell Physiol. 1981, 22, 867-880. [CrossRef]

89. Jiang, M.; Zhang, J. Water stress-induced abscisic acid accumulation triggers the increased generation of reactive oxygen species and up-regulates the activities of antioxidant enzymes in maize leaves. J. Exp. Bot. 2002, 53, 2401-2410. [CrossRef] [PubMed] 
90. Law, M.Y.; Charles, S.A.; Halliwell, B. Glutathione and ascorbic acid in spinach (Spinacia oleracea) chloroplasts. The effect of hydrogen peroxide and of Paraquat. Biochem. J. 1983, 210, 899-903. [CrossRef]

91. Bradford, M.M. A rapid and sensitive method for the quantitation of microgram quantities of protein utilizing the principle of protein-dye binding. Anal. Biochem. 1976, 72, 248. [CrossRef]

92. Bates, L.S.; Waldren, R.P.; Teare, I.D. Rapid determination of free proline for water-stress studies. Plant Soil 1973, 39, 205-207. [CrossRef]

(C) 2020 by the authors. Licensee MDPI, Basel, Switzerland. This article is an open access article distributed under the terms and conditions of the Creative Commons Attribution (CC BY) license (http://creativecommons.org/licenses/by/4.0/). 